Policy Research Working Paper 2557

Decentralization and voters in India are more Accountability

vigilant in monitoring

government at the local than

at the national level. In state

Are Voters More Vigilant in Local than in National Elections?

assembly elections voters

reward incumbents for local

income growth, and punish

them for a rise in inequality,

Stuti Khemani

over their entire term in office.

But in national elections

voters behave myopically.

rewarding growth in national

income and a fall in inflation

and inequality only in the

year preceding the election.

The World Bank

Development Research Group

Public Economics

February 2001

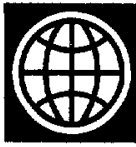


Policy Research Working Paper 2557

\section{Summary findings}

Defining vigilance as retrospective voting-where voters evaluate incumbents on their performance during their entire term in office-Khemani compares voter behavior in local and national elections to make inferences about whether voters are more vigilant in monitoring government at the local level. Using data from 14 major states in India over the period 1960-92, she contrasts voters' behavior in state legislative assembly elections with their behavior in national legislative elections.
In state assembly elections voters reward incumbents for local income growth, and punish them for a rise in inequality, over their entire term in office. But in national elections voters behave myopically, rewarding growth in national income and a fall in inflation and inequality only in the year preceding the election.

The evidence is consistent with greater voter vigilance and government accountability in local than in national elections.

This paper-a product of Public Economics, Development Research Group, is part of a larger effort in the group to understand the role of decentralization in improving public service delivery. Copies of the paper are available free from the World Bank, 1818 H Street NW, Washington, DC 20433. Please contact Hedy Sladovich, room MC2-609, telephone 202473-7698, fax 202-522-1154, email address hsladovich@worldbank.org. Policy Research Working Papers are also posted on the Web at http://econ.worldbank.org. The author may be contacted at skhemani@worldbank.org. February 2001 . (23 pages)

The Policy Research Working Paper Series disseminates the findings of work in progress to encourage the exchange of ideas about development issues. An objective of the series is to get the findings out quickly, even if the presentations are less than fully polished. The papers carry the names of the authors and should be cited accordingly. The findings, interpretations, and conclusions expressed in this paper are entirely those of the authors. They do not necessarily represent the view of the World Bank, its Executive Directors, or the countries they represent. 


\title{
Decentralization and Accountability: Are Voters More Vigilant in Local than in National Elections?
}

\author{
Stuti Khemani
}

I am grateful to Shantayanan Devarajan, Gunnar Eskeland, Dilip Mookherjee, and participants at the Annual Bank Conference on Development Economics, April 2000, for useful comments and suggestions. Correspondence may be sent via email to skhemani@worldbank.org 



\section{Introduction}

Traditional analyses of the appropriate degree of decentralization (Tiebout 1956 and Oates 1972) have emphasized the role of local governments in providing differentiated public goods in response to heterogeneous preferences. The arguments are usually based on competition across local jurisdictions, or informational advantages at more local levels. However recently, more explicit political economy analysis of incentives in the public sector (Besley and Coate 1999, Persson and Tabellini 2000, Seabright 1996) has placed political accountability at the crux of the debate on decentralization. An appealing argument in this vein is that citizens exert greater effort in monitoring government agencies when they are more local, and hence decentralization increases accountability by bringing government closer to the people (Devarajan, Eskeland and Zou 1999). One of the mechanisms by which a populace monitors government is the electoral mechanism. This paper compares voter behavior in local versus national elections to make inferences about the relative level of electoral accountability. We use data on votes cast for incumbent governments to analyze whether voters are more vigilant in local versus national elections. Specifically, we contrast the determinants of incumbent support in state legislative assembly elections in India with that in elections to the national legislature, over the period 1960-92, for 14 major states in the country.

At the outset, we define what we mean by "vigilance" of voters and provide some support from political economy theory for why this may be a reasonable definition, given our immediate objective of comparing accountability of central and local governments. For our purposes, vigilant voters are retrospective voters who evaluate incumbents on the basis of their overall performance during the entire term in office. Hence, they are defined as the opposite of myopic voters who care only about outcomes immediately before elections. This definition is based upon a moral hazard model (as in Ferejohn 1986) where all politicians are of the same "type" (that is, there is no adverse selection) and the objective of the principals (the voters) is to choose a decision rule that maximizes their well-being subject to the constraint that political agents pursue their own selfinterest. Ferejohn (1986) shows that one implication of this model is that voters should 
make their decision about reelection based on actual performance in office rather than on announced policy platforms. Therefore, our definition of vigilance is derived by extending the same idea to a setting where there are multiple periods between elections and voters need to provide incentives for good performance throughout the term in office. The goal of this paper is to study voting behavior in state and national elections in India to infer whether voters are more vigilant when evaluating incumbents at the more local level of government.

It is important to immediately highlight that the approach used in this paper is only useful to compare the relative accountability of national and local governments in some form of a principal-agent model, because the argument for retrospective voting as desirable behavior that promotes electorate interests may be turned on its head when we consider adverse selection models where politicians are differentiated by competency levels. Alesina and Rosenthal (1995) show that if incumbents receive competency shocks that are persistent, then it may be perfectly rational for voters to ignore any observations of performance before the election year, since only the most recent observation contains information about the expected performance of the office-holder in the future. However, as long as there is some delay in learning about competence, or if it is persistent for more than one period, ever adverse selection models would predict that voters should consider past observations of performance in deciding which candidate would deliver the greatest well-being in the future.

There exists a large empirical literature that tests whether the performance of the economy just before elections has a significant influence on the electoral fortunes of the president and his party in US elections, beginning with the provocative study of Kramer (1971). The motivation behind this body of work seems to be to identify the issues that matter to voters, whether income growth, unemployment, inflation, or ideological differences between the two main political parties. The general conclusion is that high income growth, and, to a lesser extent, low unemployment and inflation, just before elections has a significant positive effect on votes received by the incumbent president's party, a phenomenon that has been termed "economic retrospective voting" (Fiorina 1978). However, Stigler (1973) and Peltzman (1990) have pointed out that these studies 
assume that voters behave myopically by only considering outcomes in the recent past, usually in just the year before elections. Instead, Peltzman (1990) proposes that an appropriate model to judge voting behavior should be similar to a principal-agent model of the stock market where the owner compensates a manager based on all available information from past performance. Our definition of vigilance corresponds exactly to one essential implication of this model, namely, that voters should consider economic information available for all periods since the previous election. Peltzman's results are consistent with voters using substantial macroeconomic information to evaluate the performance of the president's party.

To the best of our knowledge, no empirical study undertakes a comparative analysis of voter behavior in national versus local elections. Although Peltzman (1992) does study voter response to fiscal policy in both presidential and gubernatorial elections, his focus is entirely on testing voter preferences with regard to growth in government budgets, assuming that the decisionmaking behavior is the same in both elections. He finds that voters penalize both federal and state spending growth, and make their decision by considering budget information for several periods before elections. Inferences based on his regressions suggest that there is no difference between voting behavior in US presidential and gubernatorial elections in terms of vigilance of voters. In his earlier study, Peltzman (1990) argues that macroeconomic conditions such as income growth, unemployment and inflation should only matter for presidential elections, and in senatorial or gubernatorial elections only as a signal to the president's party. His empirical analysis is consistent with this, although he does not explicitly test the effect of local economic conditions on gubernatorial votes.

The discussion of the Peltzman papers on voting behavior brings us to an important limitation of using this approach to make inferences about relative electoral accountability at local and national levels. Since we study voting behavior within a given federal structure, that is, a system where local and national governments have distinct roles and responsibilities, we should expect rational voters to hold the different tiers responsible for different activities. Ideally, we would like to study the effect of shifting a particular responsibility from the national to the local level of government. Hence, it may 
be that voters appear less vigilant in elections to a particular tier, but only because the activity they need to evaluate is more noisy, and not because they exert less effort in monitoring. For example, if national governments are only held responsible for general crisis management or foreign policy, then it may be that events just before elections will have a strong effect on votes. On the other hand, if local governments are held responsible for overall well-being, then voters may be more likely to consider performance throughout the term in office. Our empirical strategy focuses on studying voter responses to general economic well-being in both local and national elections, and we argue that this allows us to draw some conclusions regarding relative electoral accountability at local and national levels.

The results of the analysis may be summarized as follows: in state assembly elections, voters in India reward incumbents for local income growth, and punish them for growth in inequality, over the entire term in office. However, in national elections voters behave myopically by rewarding growth in national income and fall in inflation only in the year immediately before elections. We conclude that the evidence is consistent with greater voter vigilance and government accountability in more local elections. The pattern of results shows that voters hold the national government responsible for national growth and local governments for local growth. National governments appear to be exclusively accountable for inflation, which may be expected from intelligent voters since monetary authority rests there. ${ }^{1}$ Both tiers of government are rewarded for lowering inequality, but once again, voters in national elections place a disproportionate weight on reductions in inequality just before elections. Additional results with regard to spending and taxes at the state level suggest that voters are not swayed by increases in spending and fall in taxes just before elections. This once again confirms the conclusion that voters are vigilant in state elections, and consider performance throughout the term in office rather than being persuaded by short-term, manipulative policies just before elections. Similar analysis with fiscal variables at the national level has been difficult because of extreme multicollinearity problems, since

\footnotetext{
${ }^{1}$ Although state governments have a role to play in determining the cost of living within their boundaries via restrictions on inter-sale trade of commodities.
} 
national variables do not vary across states. With data on national spending at the state level it may be possible to draw more reliable conclusions, but this is not available at the current time.

The rest of the paper is organized as follows: section II describes the empirical strategy employed to test the hypotheses of relative voter vigilance; section III outlines the data and variables used in the analysis, and section IV reports the results of the estimation; section $\mathrm{V}$ provides further discussion about the reasoning behind the evidence, and then concludes.

\section{Empirical Strategy}

The empirical strategy consists of testing whether information from the incumbent's early years in office is a significant determinant of incumbent support, even after controlling for information available immediately prior to elections. The analysis primarily focuses on information related to changes in economic conditions, including economic growth, inflation, poverty, and income inequality. In estimating the effect of these variables, we control for several different socioeconomic and political factors that may have significant bearing on voting decisions. These include variables measuring the degree of political competition, political affiliation between the center and the state, and initial economic conditions, such as the proportion of rural population, and levels of state income, poverty and inequality. Some of these variables may be interpreted as influencing the proportion of partisan voters in the voting population. These are voters for whom the ideological position of candidates, whether based on party affiliation, religion, ethnicity, linguistics etc., matters more than their performance in delivering better economic conditions. In fact, a large number of voters are probably motivated by partisan considerations rather than by macroeconomic conditions. After controlling for these variables, our empirical estimation of the effect of economic conditions reflects the decision of the "marginal voter" (Peltzman 1990), that is, one who is indifferent between candidates or parties on ideological grounds, and votes based on economic information. 
The basic equations estimated are:

(1) $L O C A L-V O T E_{i t}=\alpha_{i}^{L}+\beta_{L} \frac{1}{(T-1)} \Sigma^{T} E C O N_{i t-2}+\beta_{L}^{-1} E C O N_{i t-1}+\gamma_{L} Z_{i t-1}+\varepsilon_{i t}^{L}$

(2) $N A T N^{\prime} L-V O T E_{i t}=\alpha_{i}^{N}+\beta_{N} \frac{1}{(T-1)} \sum^{T} \operatorname{ECON}_{i t-2}+\beta_{N}^{-1} E C O N_{i t-1}+\gamma_{N} Z_{i t-1}+\varepsilon_{i t}^{N}$

where $L O C A L-V O T E_{i t}$ is the proportion of votes received by the incumbent political party in the legislative assembly of state $i$ in state election year $t$, and NATN'L-VOTE $E_{i t}$ is the proportion of votes received by the incumbent political party in the national legislature in state $i$ in national election year $t ; E C O N_{i t}$ is the vector of economic performance variables, $Z_{i t}$ is the vector of control variables for socioeconomic and political factors, $T$ is the number of years since the previous election, $\alpha_{i}$ is an individual effect for state $i$, and $\varepsilon_{i t}$ is the unobserved error. The individual effects are estimated as fixed effects in order to identify the effect of performance on votes through intertemporal variation within a state, as opposed to cross-sectional variation across states.

The coefficients $\beta_{L}$ and $\beta_{N}$ are estimates of the marginal weight voters attach to the information received in the early years in the incumbent's term in office, after controlling for the information received just before elections. Therefore, if voters are myopic only $\beta_{k}^{-1}$ will be significant, and $\beta_{k}$ will be insignificant, that is, voters do not pay attention to the early years in the incumbent's term when evaluating his/her performance. ${ }^{2}$ In contrast, if voters are vigilant we expect $\beta_{k}$ to be statistically significant.

There are two potential econometric problems that may bias our estimates of the $\beta$ s. One is an omitted variable problem where the economic variables may be correlated with some unobservable event, or external "shock," that has an independent effect on political

\footnotetext{
${ }^{2}$ We are assuming here that only new information affects the marginal voter's decision. Therefore, if an election occurred at $t=0$, and the next one at $t=5$, then for the second election we ignore all information prior to $t=0$. This information was fully known at $t=0$, and therefore incorporated into the vote on that day. There are several caveats to this model, since principals may use old information strategically, but for our current purposes it will be instructive to look at the simple case of contrasting the whole term with the year just before elections.
} 
support for the incumbent or his party. This problem is less important if elections occur according to an exogenously determined schedule, because then our observation of voting patterns (which depends entirely on the timing of elections) is independent of the emergence of sudden crisis situations. Therefore, in our empirical analysis we check the robustness of the results to including only those elections that occurred according to a constitutionally established schedule. The second problem is an endogeneity issue, since rational politicians should choose their actions in anticipation of voter responses, and political actions should affect performance, since otherwise voters would not make decisions based upon them. If voters are not myopic, this bias would lead $\beta_{k}$, the coefficient on conditions in the early years in office, to be more likely to be significant since the values of $E C O N_{i t}$ will be restricted to a range to which voters respond favorably. Hence, although the bias will make it easier for us to find evidence in favor of vigilance, it will stem from the same source as the type of behavior we want to detect. On the other hand, if we do not find $\beta_{k}$ significant, then, in the presence of the endogeneity bias, our conclusion that voters are not vigilant is stronger. If politicians know that voters are myopic and manipulate policy to improve conditions just before elections, then the coefficient $\beta_{k}^{-1}$ is more likely to be significant since, now, the values of $E C O N_{i t-1}$ will be restricted to the favorable range. Again, the bias makes it easier to find evidence of myopic behavior, but precisely because of the presence of such behavior. There may be other reasons for voters to place a larger weight on observations just before elections (for example, if there are persistent competency shocks), but if we find $\beta_{k}$ significant even after controlling for $E C O N_{i t-1}$ we may still conclude that voters are vigilant. ${ }^{3}$

Another question that arises with regard to our estimation strategy is why use specification (1) and (2) instead of a full distributed lag model, where the test of vigilance is a joint test of the significance of the coefficients on the lags for performance in the early years in office. The obvious reason for not choosing the latter approach is because it

\footnotetext{
${ }^{3}$ This same reasoning applies if politicians are myopic, or if they incorrectly assume that voters can be swayed by election-year policy maneuverings.
} 
would lead to both a loss in degrees of freedom ${ }^{4}$ and to imprecise estimates because of multicollinearity. Furthermore, an argument can be made that voters themselves make decisions by considering average performance over the term in office.

The empirical approach here needs to contend with the trade-off between omitted variable bias and the problem of multicollinearity between variables. The inclusion of several socioeconomic variables are good controls for unobservable events that could be driving the results, but at the same time they may be highly correlated with each other, and lead to losses in degrees of freedom. All results reported here have been checked for robustness to the inclusion or exclusion of variables.

\section{Data and Variables}

The data set for this study is compiled from diverse sources for 14 major states of India over the period 1960-92. The state-level data set is described in detail in Khemani (2000). Data on national growth and fiscal variables is obtained from the budget documents of the Government of India (GOI) that are presented in various volumes of the Handbook of Statistics on Indian Economy, published by the Reserve Bank of India. The political data on elections is derived from Butler, Lahiri and Roy (1995).

Table 1 presents the variables included in several estimations of specifications (1) and (2), along with their means and standard deviations. The variables listed under the head of economic performance are included in the vector $E C O N_{i t}$, and those listed under control variables are included in $Z_{i t}$. The fiscal variables at the state level were added on to specification (1) to test voter responses to tax and spending policies. Because of the diversity of sources, and the particular nature of the voting data, the time period covered varies across variables. The empirical analysis also tests for the robustness of the evidence to changing samples when variables are included or excluded from the analysis.

\footnotetext{
${ }^{4}$ Since observations on voting patterns are only available when elections occur, we have a small sample to begin with.
} 


\section{Results}

In Tables 2 and 3, we present the coefficient estimates on economic conditions derived from the specifications in equations (1) and (2) respectively, including all the variables listed in Table 1 (except for national growth and the fiscal variables). The full regressions are reported in the appendix, in tables A.1 and A.2. Table 2 reports the results for local elections. Here, the coefficient on average growth in the early years in office is significant, thereby implying that voters consider performance throughout the entire term of the incumbent. In fact, the coefficient on average growth is larger (although the difference is not statistically significant) than the effect just in the last year in office, which means that voters reward the incumbent more when growth is sustained over several periods. The point estimate shows that a 1 percent increase in average growth leads to a 1 percentage point increase in the proportion of votes received by the incumbent. Voters punish incumbents in local elections if inequality increases during their term in office-a 1 percent increase in average inequality in the early years (as measured by the growth in the Gini coefficient) leads to a fall of about 1.5 percentage points in the incumbent's share of votes. The coefficient on average inequality is statistically greater than that on inequality just before elections (at the 10 percent level). Again, voters value consistent reductions in inequality over the term in office more than a one-shot reduction just before elections. After controlling for growth and inequality, there is no significant effect of local poverty and inflation on support for the incumbent.

In Table 3 we show the estimates for the effect of economic conditions on the proportion of votes received by incumbents in national elections. There is no effect of local growth, but voters punish national incumbents for high inflation just before elections. If inflation increases by 1 percent in the year before elections, then the proportion of votes falls by almost 1 percent. Surprisingly, average inflation in the early years in office has a positive effect. This could be because inflation is picking up some of the effect of greater national, as opposed to local, growth, and voters may hold the federal government responsible for national growth. Therefore, we reestimated specification (2) by including national growth. The result is reported in Table 4 . Now, average inflation is 
insignificant, but inflation before elections continues to have a significant negative effect, although it is smaller in size.

Voters reward incumbents for high national growth in the year just before elections. There is no added benefit to the incumbent from keeping growth high in other years in office. Table 4 shows that if national growth just before elections increases by 1 percent, the proportion of votes for the national incumbent increases by more than 1.5 percentage points. This evidence is consistent with voter myopia in national elections with regard to evaluating incumbents on the basis of performance in improving national growth and reducing inflation. Including national growth in the regression for local elections had no effect on the other parameter estimates, and national growth itself was not a significant determinant of incumbent support in local elections (with a $t$-statistic as low as 0.62 ).

Tables 3 and 4 also show that voters punish national incumbents for rising inequality. The coefficient estimates indicate that if inequality increases by 1 percent just before elections, then the incumbent's share of votes falls by almost 1.5 percentage points. Average growth in inequality in the early years in office also has a significant negative effect, but the point-estimate of the coefficient is actually smaller, thus suggesting that the incumbent can get the same increase in votes by reducing inequality just before elections, as by reducing it in all the early years in office. This once again points towards voters' myopic evaluation of performance of national incumbents. ${ }^{5}$

Fron the results discussed above, it appears that national governments are held responsible for national growth and local governments for local growth. Inflation appears to be considered the responsibility of the national government, since monetary authority is exclusively exercised by it, although in India, state governments may influence changes in the cost of living within their boundaries by their power to restrict interstate trade. Both levels of government are held accountable for redistributive policies that affect inequality. This pattern is upheld in several alternate specifications: national

\footnotetext{
${ }^{5}$ Growth in poverty just before elections is positively correlated with support for the national incumbent. This puzzling result seems to be due to correlation between the level and growth of poverty just before elections, since when the poverty level is excluded from the regression, the coefficient on poverty growth becomes insignificant.
} 
growth and inflation were never significant in the equation for local elections, and local growth was not significant in the equation for national elections.

The results discussed above regarding local and national growth, inflation, and inequality are robust to the inclusion or exclusion of different control variables, or different combinations of the performance variables.

All the results thus far are based on voting data obtained from elections that occurred at least three years after the previous one. The constitution of India schedules elections to occur every five years, so some of the elections that occur before that time may be precipitated by unobserved events that affect both the economic performance variables and voters' evaluation of incumbents. Therefore, in Tables A.3 and A.4 we present the results obtained by restricting observations to just those elections that occurred according to the constitutionally established schedule. This restriction leads to a large loss in degrees of freedom (by at least 35 per cent), and therefore, the coefficients are estimated much more imprecisely. However, the general pattern of the results for state elections (Table A.3) appears to be maintained.

The results for national elections are much more sensitive to selection of observations on the basis of the timing of elections. In Table A.4 we see that the coefficient on national growth just before elections switches sign, that is, high growth just before elections is correlated with a fall in incumbent support. However, the coefficient is barely significant at the 10 percent level. Inflation is also insignificant, but maintains the negative sign. The inequality results now show a clearer sign of myopic behavior, with only inequality just before elections affecting voters' evaluation of the national incumbent. In general, no variable related to average performance in the early years in office is significant.

The switch in sign of the effect of national growth may be driven by the exclusion of election year 1980, which occurred three years after the post-emergency election of 1977. In 1977, the traditional dominance of the Congress party in the national assembly was broken by a loose coalition called the Janata Party. However, in the next election in 1980 , the Janata Party collapsed, receiving, on average, only 18 percent of the total votes. 
At the same time, national growth in 1979 (the year just before the election) was at an all time low of -7 percent. Hence, the large correlation between output deceleration and fall of a new and fragile coalition may have been driving the positive relation between national growth just before elections and incumbent support. When this "event" is removed from estimation, the relation between these variables appears to be negative. In light of this evidence, we may need to reinterpret the relation between national growth and incumbent support in national elections. Perhaps the national growth variable reflects the effect of actions taken by central governments just before elections in order to influence the probability of reelection. In any case, the fact that only observations just before elections matter for voter response once again confirms that voters are more myopic in national elections.

Table 5 presents a regression on incumbent votes in local elections that adds state fiscal variables to specification (1). There is no evidence that populist spending increases or tax breaks just before elections leads to greater support for the incumbent. In fact, average spending on food subsidies during the term in office has a significant negative effect on votes received by the incumbent. This is a startling result, in opposition with the conventional wisdom that the food subsidy is a powerful political tool to sway the mass of uninformed voters. The result is also extremely robust to a variety of alternate specifications. It may be that this reflects voter response to other political weaknesses in the incumbent government, which drives the latter to use food subsidies as an instrument of appeasement. In addition, increases in current account spending and fall in commodity taxes just before elections are also correlated with a fall in incumbent support. On average, voters appear to dislike high investment spending and high commodity taxes. However, all the results on the fiscal variables imply very low "elasticities" for voter responses. For example, at the sample mean, a 1 percent increase in average food subsidies leads to a fall in incumbent votes by only 0.02 percentage points; a 1 percent increase in average commodity taxes lead to a fall in votes of only 0.4 percentage points; and a 1 percent increase in consumption spending before elections leads to fall in votes of only 0.2 percentage points. 
With regard to the control variables, the strength of the opposition (as measured by percentage of votes received by the main opposition party) in both local and national elections has a significant negative effect on votes for the incumbent. In national elections, state income and poverty levels also tend to have a negative effect on incumbent support. There is no significant shift in the pattern of incumbent votes after the watershed elections of 1977 when the dominance of the Congress party at the center was first challenged, as a direct consequence of the state of emergency imposed by Prime Minister Indira Gandhi from 1975 to 1977 . There is also no evidence of strategic voting based on political affiliation between central and local governments.

\section{Discussion and Conclusion}

In this paper, we have interpreted voter responses to economic performance in local and national elections as evidence that voters are more vigilant in monitoring the more local level of government. The argument is based on strong evidence that while voters reward local incumbents for high growth and low inequality throughout their term in office, they evaluate national incumbents only on the basis of performance just before elections. The proportion of votes received by the national incumbent increases with high national growth and low inflation just before elections. The comparison is partly based on distinct responsibilities of local and national governments, local growth for the local government, and national growth and inflation for the national government, although both tiers seem to be held accountable for reducing inequality. In addition, the conclusion of voter vigilance in local elections is reinforced by evidence on voter response to local fiscal policy, which implies that voters do not get swayed by preelectoral spending or tax breaks.

However, the story with regard to national elections exhibits a twist when we restrict attention only to constitutionally scheduled elections, as opposed to sudden, midterm elections. In this sample, national growth just before elections is negatively correlated with the proportion of votes received by the national incumbent, a counterintuitive relation that is difficult to interpret as the result of voter evaluation of growth performance. Instead, it is probable that preelectoral growth is a good proxy for other 
actions taken by the national government to influence voters, an interpretation that is still consistent with a story of voter myopia in national elections.

There is, however, an alternate explanation for the pattern of results obtained here that must be acknowledged. It may be that voters in the Indian federation hold the national government responsible for foreign policy, monetary policy, and overall coordination of public policies in the country, while state governments are perceived as having a bigger and direct impact on quality of life. This view would be consistent with the large developmental role assigned to state governments by the Indian constitution. Hence, if the voter choice problem is one of policing moral hazard in state government, and choosing the best candidate for the national office, then the evidence would be consistent with voter vigilance towards both tiers of government. An adverse selection model for the choice of the national candidate may easily predict more prospective behavior, where judgements about competence are made based on performance and actions just before elections.

We argue that even if the above interpretation is true, the evidence here still points to greater accountability at the more local level of government, both in terms of greater expectations of voters and greater risk of losing office owing to bad performance. Seabright (1996), in fact, defines accountability as the reduced probability that the welfare of a region affects the reelection of government. Here, incumbents in local elections are more likely to lose votes due to a fall in welfare (measured by changes in growth and inequality) at any point during their term in office. National incumbents, on the other hand, may garner a higher percentage of votes simply by focusing on events just before elections. In fact, it would be interesting to compare evidence on political cycles in public policy at national and local levels to see if national politicians are more likely to manipulate policies just before elections. Khemani (2000) finds that political cycles in state fiscal policy are rather small in magnitude, with no effect on the deficit, and argues that the pattern of evidence does not imply political efforts to woo a mass of uninformed voters. There is a larger cycle in public service delivery by state governments, but that could also be consistent with high political discount rates due to intense political uncertainties. Karnik (1990) and Sen and Vaidya (1994) test for political cycles in 
national fiscal and monetary policy, and find that the revenue deficit clearly increases just before national elections, through both tax cuts and spending increases. The deficit also appears to be monetized, with a significant increase in credits received by the national government from the Reserve Bank of India. This initial comparison would appear to suggest greater preelectoral policy manipulation by politicians in national elections. ${ }^{6}$

The Indian evidence appears to be at odds with the large body of evidence available for voting behavior in U.S. elections. In particular, Peltzman (1990) finds that voters are very sophisticated in handling macroeconomic information to make voting decisions in presidential elections, including using past information from early years in office. Furthermore, voter participation is reported to be much lower in U.S. state and local elections than in the presidential race. What accounts for this discrepancy between these two large democracies? One hypothesis may be that greater geographic mobility in the U.S. allows voters to "vote with their feet" (as in Tiebout 1956) and therefore, the electoral mechanism of inducing local governments to perform in the interests of the public is a weaker instrument. ${ }^{7}$ Future research on the effect of factor mobility on electoral participation in local government may be an interesting exploration of the Tiebout hypothesis.

In conclusion, we raise some issues that are relevant to this discussion of voter behavior, decentralization, and accountability, but have not been addressed here and may be valuable topics for future work. First, to the best of our knowledge, there does not appear to be any theoretical model for why voters would be more vigilant in monitoring more local levels of government. The answer may lie in a Downsian cost-benefit analysis of voting behavior, but as yet the precise mechanisms by which marginal cost of informed voting is lower or marginal benefit is higher at more local levels, has not been formalized. Second, the analysis undertaken here provides no answer to the question of whether such vigilant voting in state elections in India is actually successful in providing incentives to state politicians. The answer is probably negative, because under India's

\footnotetext{
${ }^{6}$ This comparison must be taken with caution, since neither Karnik (1990) nor Sen and Vaidya (1994) distinguish between scheduled and midterm national elections, so that there results may be driven by potential endogeneity of the timing of elections.
} 
electoral laws there may be no link between electoral victory, in terms of winning a majority of seats in the state legislature, and the total proportion of votes received by the incumbent. In fact, the common experience is one of tremendous vote fragmentation in the face of a divided opposition, so that a candidate may win by a simple majority in a constituency, with as little as 20 per cent of the total valid votes (Butler et al. 1995). Therefore, interest group politics may be key to electoral victories in the legislature, because given a high average level of vote fragmentation, candidates simply have to round-up a small percentage of votes to get first past the post. Future research on electoral outcomes at the constituency level may provide a better understanding of government accountability to the electorate. Finally, this paper does not provide a detailed political analysis of voting behavior in terms of voters' ideological, partisan, or strategic responses. For example, how does the emergence of regional political parties in India affect voters' choice of candidates to the national legislature-do they strategically divide power to have different parties at the center and the state, or do they start voting for the regional party to the national legislature? The only relevant evidence that we report on this issue is that political affiliation between the central and state governments is positively correlated with the proportion of votes received by the national incumbent, but this relation is not significant.

\section{Bibliography}

Alesina, A. and Rosenthal, H. 1995. Partisan Politics, Divided Government and the Economy. Cambridge University Press.

Besley, T. and Coate, S. 1999. "Centralized versus decentralized provision of local public goods: a political economy analysis," NBER working paper 7084

Butler, D., Lahiri, A. and Roy, P. 1995. India Decides: Elections 1952-1995, New Delhi

Devarajan, S., Eskeland, G. and Zou, H. 1999. "Decentralization and Efficiency: what should one expect?" Paper presented at the Bonn Conference on Fiscal Federalism, May 1999.

\footnotetext{
${ }^{7}$ I am indebted to Shanta Devarajan for suggesting this idea.
} 
Ferejohn, J. 1986. "Incumbent performance and electoral control," Public Choice, Vol $50,5-25$

Fiorina, M. 1978. "Economic Retrospective Voting in American Elections," American Journal of Political Science, Vol 22, 426-43

Karnik, A.V. 1990. "Elections and government expenditures: the Indian evidence," Journal of Quantitative Economics, Vol 6, 203-12

Khemani, S. 2000. "Political Cycles in a Developing Economy: Effect of Elections in the Indian States," Working paper, The World Bank

Kramer, G. 1971. "Short-term Fluctuations in U.S. Voting Behavior, 1896-1964," American Political Science Review, Vol 65, 131-43.

Oates, W. E. 1972. Fiscal Federalism, Princeton University: Harcourt Brace Jovanovich Inc., New York

Peltzman, S. 1992. "Voters as Fiscal Conservatives," Quarterly Journal of Economics, Vol 107(2), 327-361

Peltzman, S. 1990. "How Efficient is the Voting Market?" Journal of Law and Economics, Vol 33, 27-64.

Persson, T. and Tabellini, G. 1999. "Political Economics and Public Finance," NBER working paper 7097

Seabright, P. 1996. "Accountability and decentralization in government: an incomplete contracts model," European Economic Review, Vol 40, 61-89.

Sen, K. and Vaidya, R. 1994. "Political budget cycles in India," Discussion paper no. 104, Indira Gandhi Institute of Development Research, Mumbai

Stigler, G. 1973. "General Economic Conditions and National Elections," American Economic Review, Vol 63, 160-67.

Tiebout, C. M. 1956. "A pure theory of local expenditures," Journal of Political Economy, Vol 64, 416-24. 


\begin{tabular}{|l|c|c|}
\hline Table 1. Variable Dictionary and Summary Statistics \\
\hline Name & Mean & Std. Dev. \\
\hline Dependent variables: & & \\
\hline Votes for state incumbent (percent) & 35.27 & 12.02 \\
\hline Votes for national incumbent (percent) & 35.86 & 15.74 \\
\hline Economic performance: & & \\
\hline Local growth & 2.28 & 10.21 \\
\hline National growth & 2.12 & 3.35 \\
\hline Rate of inflation & 6.68 & 9.82 \\
\hline Growth in poverty & -0.18 & 10.86 \\
\hline Growth in inequality & 0.03 & 7.70 \\
\hline Control variables: & & \\
\hline State income per capita & 1080.31 & 556.10 \\
\hline Poverty (headcount index) & 53.12 & 12.96 \\
\hline Gini coefficient & 29.16 & 4.02 \\
\hline Proportion of agriculture in state product & 0.44 & 0.11 \\
\hline Proportion of rural population & 0.80 & 0.10 \\
\hline Political affiliation: $=1$ if central and state \\
govt. Belong to the same party, 0 otherwise & 0.61 & 0.49 \\
\hline Votes to main opposition, state (percent) & 27.22 & 13.91 \\
\hline Votes to main opposition, national (percent) & 28.94 & 18.53 \\
\hline Year 1977: =1 if year is 1977 or after & & \\
\hline Fiscal variables (state-level): & & \\
\hline Food subsidies per capita, 1973 rs. & 0.54 & 1.66 \\
\hline Consumption spending per capita, 1973 rs. & 95.88 & 57.36 \\
\hline Investment spending per capita, 1973 rs. & 23.43 & 11.72 \\
\hline Commodity taxes per capita, 1973 rs. & 58.07 & 40.39 \\
\hline
\end{tabular}

\begin{tabular}{|l|c|c|}
\hline $\begin{array}{l}\text { Table 2. Effect of Economic Performance on Incumbent Votes in Local Elections } \\
\text { (t-statistic in parenthesis) }\end{array}$ & Average in early years & $t-1$ \\
\hline Variable & 1.00 & 0.41 \\
& $(2.41)$ & $(1.60)$ \\
\hline Local Growth & 0.43 & 0.10 \\
& $(1.04)$ & $0.21)$ \\
\hline Inflation & 0.24 & 0.10 \\
& $(0.62)$ & $(0.32)$ \\
\hline Growth in Poverty & -1.51 & -0.76 \\
& $(-2.51)$ & $(-2.12)$ \\
\hline Growth in Inequality & &
\end{tabular}




\begin{tabular}{|l|c|c|}
\hline \multicolumn{3}{|c|}{ Table 3. Effect of Economic Performance on Incumbent Votes in National Elections } \\
(t-statistic in parenthesis)
\end{tabular}

\begin{tabular}{|c|c|c|}
\hline Variable & Average in early years & $t-1$ \\
\hline National Growth & $\begin{array}{c}-1.39 \\
(-0.81)\end{array}$ & $\begin{array}{c}1.66 \\
(2.08)\end{array}$ \\
\hline Local Growth & $\begin{array}{c}0.38 \\
(0.85)\end{array}$ & $\begin{array}{c}0.09 \\
(0.47)\end{array}$ \\
\hline Inflation & $\begin{array}{c}0.71 \\
(1.38)\end{array}$ & $\begin{array}{l}-0.61 \\
(-2.60)\end{array}$ \\
\hline Growth in Poverty & $\begin{array}{c}0.58 \\
(1.56)\end{array}$ & $\begin{array}{c}0.58 \\
(2.55)\end{array}$ \\
\hline Growth in Inequality & $\begin{array}{c}-1.08 \\
(-1.82)\end{array}$ & $\begin{array}{l}-1.43 \\
(-4.42)\end{array}$ \\
\hline
\end{tabular}

\begin{tabular}{|c|c|c|}
\hline Variable & Average in early years & $t-1$ \\
\hline Food Subsidies & $\begin{array}{c}-3.80 \\
(-2.70)\end{array}$ & $\begin{array}{c}-0.83 \\
(-0.48)\end{array}$ \\
\hline Consumption spending & $\begin{array}{c}0.16 \\
(1.52)\end{array}$ & $\begin{array}{c}-0.26 \\
(-2.47)\end{array}$ \\
\hline Investment spending & $\begin{array}{c}-0.50 \\
(-2.59)\end{array}$ & $\begin{array}{c}0.30 \\
(1.56)\end{array}$ \\
\hline Commodity Taxes & $\begin{array}{c}-0.83 \\
(-3.38)\end{array}$ & $\begin{array}{c}0.60 \\
(2.50)\end{array}$ \\
\hline
\end{tabular}




\begin{tabular}{|c|c|c|}
\hline \multicolumn{3}{|c|}{$\begin{array}{l}\text { Table A.1 Full Regression on Incumbent Votes in Local Elections } \\
\text { (t-statistic in parenthesis) }\end{array}$} \\
\hline Variable & Avg. in early years & $t-1$ \\
\hline Local Growth & $\begin{array}{c}1.00 \\
(2.41)\end{array}$ & $\begin{array}{c}0.41 \\
(1.60)\end{array}$ \\
\hline Inflation & $\begin{array}{c}0.43 \\
(1.04)\end{array}$ & $\begin{array}{c}0.10 \\
(0.21)\end{array}$ \\
\hline Growth in Poverty & $\begin{array}{c}0.24 \\
(0.62)\end{array}$ & $\begin{array}{c}0.10 \\
(0.32)\end{array}$ \\
\hline Growth in Inequality & $\begin{array}{l}-1.51 \\
(-2.51)\end{array}$ & $\begin{array}{c}-0.76 \\
(-2.12)\end{array}$ \\
\hline Proportion of agriculture in state income & & $\begin{array}{l}22.31 \\
(0.53)\end{array}$ \\
\hline Proportion of rural population & & $\begin{array}{l}178.6 \\
(1.13)\end{array}$ \\
\hline State income per capita & & $\begin{array}{c}-0.01 \\
(-1.09)\end{array}$ \\
\hline Gini coefficient & & $\begin{array}{c}0.20 \\
(0.28)\end{array}$ \\
\hline Poverty index & & $\begin{array}{c}-0.50 \\
(-1.26)\end{array}$ \\
\hline Indicator for year 1977 and after & \multicolumn{2}{|c|}{$\begin{array}{c}2.17 \\
(0.33)\end{array}$} \\
\hline Affiliation between state and center & \multicolumn{2}{|c|}{$\begin{array}{c}-0.62 \\
(-0.18)\end{array}$} \\
\hline Opposition strength & \multicolumn{2}{|c|}{$\begin{array}{l}-0.48 \\
(-3.65)\end{array}$} \\
\hline \multicolumn{3}{|l|}{ No. of observations: 77} \\
\hline R-sq: 0.61 & & \\
\hline
\end{tabular}




\begin{tabular}{|c|c|c|}
\hline \multicolumn{3}{|c|}{$\begin{array}{l}\text { Table A.2 Full Regression on Incumbent Votes in National Elections } \\
\text { (t-statistic in parenthesis) }\end{array}$} \\
\hline Variable & Avg. in early years & $t-1$ \\
\hline National Growth & $\begin{array}{l}-1.39 \\
(-0.81)\end{array}$ & $\begin{array}{c}1.66 \\
(2.08)\end{array}$ \\
\hline Local Growth & $\begin{array}{c}0.38 \\
(0.85)\end{array}$ & $\begin{array}{c}0.09 \\
(0.47)\end{array}$ \\
\hline Inflation & $\begin{array}{c}0.71 \\
(1.38)\end{array}$ & $\begin{array}{l}-0.61 \\
(-2.60)\end{array}$ \\
\hline Growth in Poverty & $\begin{array}{c}0.58 \\
(1.56)\end{array}$ & $\begin{array}{c}0.58 \\
(2.55)\end{array}$ \\
\hline Growth in Inequality & $\begin{array}{l}-1.08 \\
(-1.82)\end{array}$ & $\begin{array}{l}-1.43 \\
(-4.42)\end{array}$ \\
\hline Proportion of agriculture in state income & & $\begin{array}{l}-8.18 \\
(-0.18)\end{array}$ \\
\hline Proportion of rural population & & $\begin{array}{l}64.97 \\
(0.36)\end{array}$ \\
\hline State income per capita & & $\begin{array}{l}-0.03 \\
(-2.97)\end{array}$ \\
\hline Gini coefficient & & $\begin{array}{c}0.75 \\
(0.99)\end{array}$ \\
\hline Poverty index & & $\begin{array}{l}-0.59 \\
(-2.02)\end{array}$ \\
\hline Indicator for year 1977 and after & \multicolumn{2}{|c|}{$\begin{array}{c}4.34 \\
(0.47)\end{array}$} \\
\hline Affiliation between state and center & \multicolumn{2}{|c|}{$\begin{array}{c}3.45 \\
(1.16)\end{array}$} \\
\hline Opposition strength & \multicolumn{2}{|c|}{$\begin{array}{l}-0.25 \\
(-2.60)\end{array}$} \\
\hline \multicolumn{3}{|l|}{ No. of observations: 76} \\
\hline R-sq: 0.70 & & \\
\hline
\end{tabular}




\begin{tabular}{|c|c|c|}
\hline Variable & Avg. in early years & $t-1$ \\
\hline Local Growth & $\begin{array}{c}1.27 \\
(1.63)\end{array}$ & $\begin{array}{c}0.29 \\
(0.85)\end{array}$ \\
\hline Inflation & $\begin{array}{c}0.79 \\
(1.02)\end{array}$ & $\begin{array}{c}0.39 \\
(1.03)\end{array}$ \\
\hline Growth in Poverty & $\begin{array}{c}-0.18 \\
(-0.42)\end{array}$ & $\begin{array}{c}-0.36 \\
(-1.27)\end{array}$ \\
\hline Growth in Inequality & $\begin{array}{c}-0.89 \\
(-1.26)\end{array}$ & $\begin{array}{c}-0.34 \\
(-0.82)\end{array}$ \\
\hline Proportion of agriculture in state income & & $\begin{array}{c}-48.36 \\
(-0.83)\end{array}$ \\
\hline Proportion of rural population & & $\begin{array}{r}29.55 \\
(0.12) \\
\end{array}$ \\
\hline State income per capita & & $\begin{array}{c}-0.01 \\
(-0.87)\end{array}$ \\
\hline Gini coefficient & & $\begin{array}{c}0.12 \\
(0.17)\end{array}$ \\
\hline Poverty index & & $\begin{array}{c}0.13 \\
(0.28)\end{array}$ \\
\hline Indicator for year 1977 and after & \multicolumn{2}{|c|}{$\begin{array}{c}-6.99 \\
(-0.80)\end{array}$} \\
\hline Affiliation between state and center & \multicolumn{2}{|c|}{$\begin{array}{c}5.30 \\
(1.08)\end{array}$} \\
\hline Opposition strength & \multicolumn{2}{|c|}{$\begin{array}{c}-0.26 \\
(-1.71) \\
\end{array}$} \\
\hline \multicolumn{3}{|l|}{ No. of observations: 55} \\
\hline R-sq: 0.72 & & \\
\hline
\end{tabular}




\begin{tabular}{|c|c|c|}
\hline \multicolumn{3}{|c|}{$\begin{array}{l}\text { Table A.4 Incumbent Votes in Scheduled National Elections } \\
\text { (t-statistic in parenthesis) }\end{array}$} \\
\hline Variable & Avg. in early years & $t-1$ \\
\hline National Growth & $\begin{array}{c}3.03 \\
(1.35)\end{array}$ & $\begin{array}{c}-2.79 \\
(-1.66)\end{array}$ \\
\hline Local Growth & $\begin{array}{c}0.07 \\
(0.15)\end{array}$ & $\begin{array}{c}0.20 \\
(0.98)\end{array}$ \\
\hline Inflation & $\begin{array}{l}-0.95 \\
(-1.32)\end{array}$ & $\begin{array}{l}-0.16 \\
(-0.60)\end{array}$ \\
\hline Growth in Poverty & $\begin{array}{c}1.12 \\
(2.57)\end{array}$ & $\begin{array}{c}0.54 \\
(2.48)\end{array}$ \\
\hline Growth in Inequality & $\begin{array}{l}-0.62 \\
(-1.00)\end{array}$ & $\begin{array}{l}-1.07 \\
(-3.29)\end{array}$ \\
\hline Proportion of agriculture in state income & & $\begin{array}{l}-36.72 \\
(-0.84)\end{array}$ \\
\hline Proportion of rural population & & $\begin{array}{l}140.3 \\
(0.75)\end{array}$ \\
\hline State income per capita & & $\begin{array}{c}-0.02 \\
(-1.47)\end{array}$ \\
\hline Gini coefficient & & $\begin{array}{c}0.07 \\
(0.07)\end{array}$ \\
\hline Poverty index & & $\begin{array}{c}-0.44 \\
(-1.48)\end{array}$ \\
\hline Indicator for year 1977 and after & \multicolumn{2}{|c|}{$\begin{array}{l}14.78 \\
(1.45)\end{array}$} \\
\hline Affiliation between state and center & \multicolumn{2}{|c|}{$\begin{array}{c}2.32 \\
(0.74)\end{array}$} \\
\hline Opposition strength & \multicolumn{2}{|c|}{$\begin{array}{c}-0.29 \\
(-3.01)\end{array}$} \\
\hline \multicolumn{3}{|l|}{ No. of observations: 63} \\
\hline R-sq: 0.64 & & \\
\hline
\end{tabular}





\section{Policy Research Working Paper Series}

Title

WPS2542 Checks and Balances, Private Information, and the Credibility of Monetary Commitments

WPS2543 When Do Special Interests Run Rampant? Disentangling the Role in Banking Crises of Elections, Incomplete Information, and Checks and Balances

WPS

WPS2544 The Uniqueness of Short-Term Collateralization

Leora Klapper

Marianne Fay

WPS2545 Financing the Future: Infrastructure Needs in Latin America, 2000-05

Philip Keefer

Paulette Castel

WPS2546 Gender Dimensions of Pension Reform in the Former Soviet Union

WPS2547 The Design of Incentives for Health Care Providers in Developing Countries: Contracts, Competition, and Cost Control

WPS2548 International Provision of Trade Services, Trade, and Fragmentation

WPS2549 Measuring Poverty Dynamics and Inequality in Transition Economies: Disentangling Real Events from Noisy Data

WPS2550 Measuring Equity in Health Care Financing: Reflections on (and Alternatives to) the World Health Organization's Fairness of Financing Index

WPS2551 Infrastructure Coverage and the Poor: A Global Perspective

Kristin Komives Dale Whittington Xun Wu

Alan V. Deardorff

Erzo F.P. Luttmer

Adam Wagstaff

J. Luis Guasch Levels and Determinants-a Red Flag Joseph Kogan For Competitiveness and Growth

WPS2553 The Value of Relationship Banking during Financial Crises: Evidence from the Republic of Korea
Giovanni Ferri Tae Soo Kang In-June Kim
February 2001

P. Sintim-Aboagye 37644

February 2001

February 2001

February 2001

A. Maranon 38009

February 2001

\section{Contact} for paper

P. Sintim-Aboagye 37644

A. Yaptenco 31823

A. François 37841

February $2001 \quad$ J. Smith 87215

February $2001 \quad H$. Sladovich 37698

L. Tabada 36896

C. Wodon 32542

February 2001

S. Minovi 30012

J. Troncoso 37826

February 2001

A. Yaptenco 31823 
Policy Research Working Paper Series

Title

WPS2554 Administrative Costs and the Organization of Individual Retirement Account Systems:

A Comparative Perspective

WPS2555 Implicit Pension Debt, Transition Cost, Options, and Impact of China's Pension Reform: A Computable General Equilibrium Analysis

WPS2556 Household Strategies for Coping with Poverty and Social Exclusion in Post-Crisis Russia
Author

Estelle James James Smalhout

Dimitri Vittas

Yan Wang

Dianqing $X_{u}$

Zhi Wang

Fan Zhai

Michael M. Lokshin

Ruslan Yemtsov
Date

February 2001

February 2001

February 2001

P. Sader

33902
Contact

for paper

A. Yaptenco

31823

A. Datoloum 36334 